\title{
Inflation, Growth, and Distribution Nexus in Post-Transition and Emerging Economies of South Asia
}

\section{Sanjaya Acharya* \\ Mohamed lleas Mia**}

\section{Summary}

This study investigates the impact of inflation on poverty and income distribution in five major economies in South Asia in the period 1986-2014. Inflation reduces the poverty rate and the poverty gap as the agricultural poor largely benefit from higher agricultural prices whereas the poorest quintile of the population who are landless farmers remain in a disadvantageous position. This raises the overall level of inequality in the economy despite poverty reduction. Trade openness is still not the engine of growth in South Asia - rather it has widened the poverty gap and aggravated inequality because the poor are not well integrated to the global market as compared to the well-off groups. As a result, there has been growing inequality across the region.

Keywords: Inflation; Growth; Poverty; Income Distribution; South Asia

JEL: E31; O47; I32; D31; O53

\section{Introduction}

\subsection{Background}

Inflation is a common problem among South Asian countries as a reflection of various factors, most importantly higher international food and fuel prices, supply constraints and various macroeconomic shocks. The majority of South Asian economies rely heavily on imports of petroleum products and some basic food items, such as edible oils. Additionally, food represents a large portion of the regional household consumption basket, a key concern from a poverty perspective. A series of local one-off factors have contributed to price pressures including the economic disruptions from flooding in Pakistan during the second half of 2010 and Sri Lanka in early 2011. Other factors pertains to the partial liberalization of petroleum prices in India in the mid-2010 and the administered rise of prices elsewhere in the region including Bhutan, the Maldives and Pakistan.

Inflation remains a key downside risk to growth, as policy makers face numerous challenges in reducing price pressures. If inflation remains elevated, it is likely to hamper the region's international competitiveness and foreign investment creating headwinds

Tribhuvan University, Faculty of Humanities and Social Sciences - Economics, Saraswati Multiple Campus, Thamel 26 Kathmandu, Nepal.

** Ministry of Public Administration, Dhaka, Bangladesh. 


\section{Articles}

in raising productivity. Fiscal slippage is contributing to inflationary pressures and limiting policy options byfuelling future crises through limited fiscal space.

South Asia's largest economy, India, is relatively less vulnerable to the current inflationary shock, largely for its higher domestic production capacity of agricultural commodities and recent appreciation in its currency, inter alia. Nevertheless, oil price volatilities in the world market remain a worry for the economy. In its 2007/08 issue of Macroeconomic and Monetary Developments, the Reserve Bank of India acknowledged, "since pass-through of higher international oil prices to domestic prices remains incomplete, inflation has remained suppressed." (RBI, 2008). The other major economies in the region Pakistan, Bangladesh, Sri Lanka that largely depend on international markets for fuel and, to a lesser extent, for non-fuel commodities, face much more daunting challenges than India in their attempts to contain inflation. The inflation scenario in Nepal is likely to follow the price level in India, largely because the former's domestic currency is pegged to the latter's currency.

South Asian countries have two pronged challenges of inflation. Firstly, galloping inflation could significantly destabilize key macro-economic variables, including gross domestic product (GDP) growth. Higher oil import bills that many economies in the region absorb through subsidies could further swell their fiscal deficits. Secondly, price volatilities pose political danger. South Asia hosts the largest number of the world's poor and the correlation between per capita income and food weight in total CPI is generally higher for low-income group consumers. The World Food Programme cautioned that the rising prices of food items might have a political cost because the marginal propensity of food consumption expenditure of poorer households is approximately 70 percent of their income (Global Wage Report, ILO, 2008/09).

The functional distribution of income is an integral part of the economic analysis of relative price movement and inflation. In this sense there are several theories of income distribution corresponding to different theoretical and ideological stances. However, these various analyses usually focus on the same basic economic concepts: employment of the factors of production i.e. land, labour and capital, and the rates of remuneration of their services, rent, wage and profit. Another approach to the growth and distribution is dualistic development. Fields (1980) uses Lorenz curves to analyze three limiting cases of dualistic development. The economy of Sri Lanka and the state of Kerala in India followed this strategy and reduced absolute poverty. In these two opposing growth strategies, growth results in higher income group under modem sector growth strategy; and a more equal relative distribution of income and less poverty in traditional sector enrichment growth strategy. In the former case, growth causes the Lorenz curve to shift uniformly upward and closer toward the line of equality but the opposite happens with the latter case (Fields, 1980).

These three growth strategies predict differently on what will happen to inequality in the course of economic growth. With modem-sector enrichment, inequality would rise steadily, while under traditional-sector enrichment, inequality would fall steadily and under modem-sector enlargement, inequality would first rise and then fall according to Kuznets inverted ' $U$ ' hypothesis (Kuznets, 1955).

The price hike of primary commodities in most South Asian countries has further worsened due to low per capita agricultural production, the Central Bank's lax monetary 


\section{Articles}

policies (or lagged effects of earlier expansionary monetary policies), undervalued exchange rate polices (economies other than India and Nepal), and internal political instabilities. Another major concern for South Asia, which is the home to the vast majority of the world's poor, is the adverse impact of inflation on the poor and other vulnerable groups in society. Since the consumption pattern of the poor is different from that of the non-poor and the poor spend a higher share of their budget on food and other essential commodities, inflation hurts the poor more than the non-poor. There are a number of studies on inflation, poverty and inequality in the case of South Asian economies. However, there is no study that examines the causal relationship among them in South Asian economies and this study intends to achieve this goal.

Against this backdrop, the objective of this study is to explore poverty and distributional impact of inflation in South Asian economies. The analysis comprises both consumer price inflation and food price inflation and their impact on poverty and distribution. In this context, the rest of this paper is organized as follows. After a brief review of poverty, inequality and food security situation in South Asia in the following section, the discussion on the theoretical debate on these issues are discussed in Section 2. The objectives and methods of this study are outlined in Section 3. The results of the analysis are the subject matter of Section 4. The paper offers conclusions and draws some implications in Section 5.

\subsection{Growth, Poverty, Inequality, and Food Security in South Asia}

Many growth promotion and poverty reduction programmes have been operational in South Asia for the last several decades. In the last 40 years Bangladesh increased real per capita income by more than $130 \%$,
Inflation, Growth, and Distribution Nexus in Post-

Transition and Emerging Economies of South Asia

cut poverty rate by $60 \%$, reduced and attained the sustained economic growth of $6 \%$ during 2000 s. Bangladesh was able to produce staple food, such as rice three times more than its production in 1973 (10 million tonnes) and nearly achieved self-sufficiency in normal weather conditions (Regional Poverty Profile: Bangladesh, SAARC, 2013). As a result Bangladesh has reduced poverty successfully since 1990. Household income and expenditure survey (HIES-2010) shows that the national head count poverty declined from 56.6 percent in 1991-92 to 31.5 percent in 2010 . Extreme poverty declined from $41 \%$ to $17.6 \%$ over the same period. Bangladesh halved the poverty by reducing the poverty gap from 17.20 in 1991-1992 to $8.60 \%$ in 2010 . The economy of Bangladesh is now far more flexible and resilient. It has withstood the adverse effect of the recent financial crisis and has also gained remarkable efficiency in handling natural disasters with minimum loss of lives and assets despite internal and external constraints.

Despite the progress made over the last 40 years, Bangladesh is still a low-income country with widespread poverty, income inequality and deprivation (World Bank, 2018). About 47 million people are living under the poverty line, among them a sizeable number are femaleheaded households, socially excluded and people living in remote areas.

India has followed inclusive growth strategy for poverty reduction (Regional Poverty Profile: India, SAARC, 2013). It has reduced head count ratio from $45.30 \%$ in 1993-94 to $37.20 \%$ in 2004-05. Head count poverty declined by around $0.8 \%$ per year. The eleventh plan took a broader target of reducing poverty by $2 \%$ a year. Household consumer expenditure survey, 2009-10 suggested the poverty to have declined by $1 \%$ since 2005 but in 2010 poverty increased as it was a drought year while the urban area 


\section{Articles}

poverty is highest among the self-employed people (28.06\%); it declined from $36.91 \%$ in 1993-94. The government of India adopted the eleventh five-year plan with an aim to achieve inclusive growth in 27 measurable targets. These targets are mostly related to the reduction of poverty.

Nepal made progress in reducing poverty during the last two decades. It made $11 \%$ reduction from $42 \%$ to $31 \%$ in head count poverty during 1994- 2004 and during 2005 2009 by $6 \%$ from $31 \%$ to $25 \%$. In 2004 , urban and rural poverty in Nepal was $10 \%$ and $35 \%$ respectively and in 2009 the poverty in both areas was reduced to $8 \%$ and $22 \%$. According to 2008 Nepal Labour Force Survey, the main source of income in rural areas is remittance. Among 4.83 million households, 1.45 million receive remittance (Regional Poverty Profile Nepal, 2010-12, SAARC, 2013). Agricultural share in GDP is approximately one third in Nepal.

Poverty in Pakistan consistently decreased during the 1970s and 1980s. According to 1995 World Bank Poverty assessment report, consumption-based poverty in Pakistan declined between 1984-85 and 1990-91. Head count poverty during 1984-85 stood at $46 \%$ and declined to $37.4 \%$ in $1987-88$ and to $34 \%$ in $1990-91$. But during the later part of the 1990s, growth rate varied largely and deteriorated the poverty scenario and widened the rural and urban poverty gap. In the ten years preceding 1990, poverty in Pakistan declined but after that period it has not declined appreciably.

Rural poverty is kept unaddressed (Pakistan Poverty Assessment, 2002). According to the latest World Bank report, Pakistan ranked most exposed to poverty risk among 43 countries and poverty jumped to $37.50 \%$ from $23.9 \%$ in three years. In its latest estimate the Planning Commission of Pakistan reported that the 64 million people are now living in poverty as opposed to 35.5 million in 2014. The main reason is connected with slow economic growth, external shock and persistent high inflation. The Planning Commission suggested that peace and order, the decentralization of development and industrial development in rural area should be prioritized.

Sri Lanka has become successful in reducing the worst form of poverty and chronic hunger based on per capita income of 1 USD a day, yet the relative consumption poverty is still high. National Head count poverty ratio was $22.7 \%$ in 2002 and was considered high because of high inequality compared to its USD 1011 per capita GDP. In 2010, the per capita GDP of Sri Lanka reached USD 2367 and poverty was down to $7.6 \%$. A large number of poor in Sri Lanka lives in rural and plantation sectors, half of the poor are employed in small-scale agriculture and wage labour in the farm and estate factors.

Introduction of open market economic policy helped reducing urban poverty in Sri Lanka, it declined from $16.3 \%$ in 1991 to $6.7 \%$ in 2002. Trickle-down effects of development to the agriculture and rural areas were slow during 1984-2010 but incidence of poverty in agricultural households declined by $13 \%$, but incidence of poverty in plantation sector increased during 1991-2002 by $46 \%$.

Sri Lanka's achievement compared to the other countries of South Asia is enviable. Sri Lanka adopted one of the two extremes of development strategies, grow now and redistribute later and grow later and redistribute now. Sri Lanka adopted the latter. The benefit of this policy along with the open market economy helped Sri Lanka attain a remarkable achievement in socio-economic sectors. Social safety net programmes were undertaken to reach the poor uncovered by the development and open market economic policy of the country. Sri Lanka is a net food 


\section{Articles}

importing country; therefore, the rise in food prices abroad can bring food price spiral in the economy. The public food distribution system in Sri Lanka, however, has contributed to its exceptional progress in the social sector. Through this system, the government supplies a specific amount of grains, particularly rice to the households, the low-income households are therefore benefited to a great extent. It decreased the income inequality. In 2002 all transfer programmes unified under Samurdhi programme and about $26.7 \%$ of all households received the benefit and it amounts to $7.7 \%$ of total monthly income of such households and the government now spends $14 \%$ of the total annual budget for food subsidy. Sri Lanka is one of the few countries in the world that has relied on food subsidy and other income transfer programmes to increase the income of the poor and control food price inflation. Though targeting household was not full proof, this enormous program eventually benefited the poor substantially (RPP: Sri Lanka, SAARC, 2013).

For the agricultural poor, employment opportunity is mainly provided during the harvesting season and this opportunity ends with the end of harvesting. In harvesting period the food prices are also affordable to the agricultural employee but during the lean period of March-April and NovemberDecember food prices are the highest while employment opportunity is at its lowest. In lean period, about $54 \%$ to $65 \%$ of the rural poor face difficulties accessing food; and the number of people experiencing food insecurity is about 65.3 million (FAO: Bangladesh Poverty Map, 2005). This is considered as the major cause that fuels inflation in Bangladesh.

India has achieved self-sufficiency in food production. Since 1970s, India hardly imported food grains and it increased food production five times from the production of 1950-51. To ensure food security, India aims
Inflation, Growth, and Distribution Nexus in Post-

Transition and Emerging Economies of South Asia

to give food security a statutory binding. According to National Food Security Bill, the government should provide subsidized ration on food for $75 \%$ of the rural people and $50 \%$ of the people living in the urban areas with 28\% priority category (RPP: India 2010-12, SAARC, 2013).

South Asian countries greatly depend on cash transfer, subsidies on food, agriculture and other social safety programmes for poverty reduction. Yet, as it appears from the above discussion, poverty is still high and the inflationary impact on growth and poverty reduction has been ignored or not yet explored seriously. Beside social safety net programmes, rising inflation's impact on poverty, and more specifically food price inflation, has a very limited research in the region. This study intends to fill this gap.

\section{Theoretical Debate}

There is an enormous literature on the impact of inflation on employment, output and economic growth (Driffill, et al., 1990, and McCallum, 1990). Yet there are limited empirical studies on inflation's effect on income distribution in an international or regional setting and, most cross-country empirical studies do not explicitly consider inflation as a determinant of income inequality (Ravallion, 1997). In this area, Blinder and Esaki (1978) and Blank and Blinder (1985) have conducted the pioneer works. Blank and Blinder (1978) have examined the business cycle, income distribution and poverty in case of USA and found that both the poverty head count ratio and the income share of the lowest quintile is pro-cyclic; unemployment, however, was found to have been a significant negative effect on the income of the poor while the effect of inflation was insignificant. Individuals and firms were better hedged against inflation by improvement in human capital, real capital 


\section{Articles}

and food supply compared to the better and improved commercial agriculture.

The redistributive role of inflation through its effect on wages has been widely covered in the literature. In persistent inflation, prices tend to run ahead of the increase in wages. Therefore, inflation leads to a shift of income away from wage earners to profit earners. On this ground, inflation is claimed to increase income inequality because it hurts the poor relatively more than the rich (Laidler and Parkin, 1975, and Fischer and Modigliani, 1978).

Another main channel through which inflation affects the income of the poor is through the cash holding. Higher inflation reduces the buying power of their savings and reduces well-being. In South Asia, the poorest households spend about $70 \%$ of their income on food (Global Wage Report, ILO, 2008/09). Therefore, non-indexed savings and income along with food price inflation from external oil price shock and internal shock caused by agricultural production pulls back the poverty alleviation initiatives. It is important to note that all the countries in South Asia are net importers of oil and heavily dependent on agriculture. Oil price increase in the world market transmits to all sectors of the economy, exerting pressure on the capital account and price stability in the domestic market that have redistributive consequences in the economy.

\subsection{Inflation and Growth}

The inflation and growth nexus has been studied in various papers but they lack robust conclusion. OECD countries' data show insignificant association between them (Grier and Tullock, 1989). From the pool of 113 countries, divided into OECD and the rest of the world for the period 1950-1981, inflation had negative and significant effect on growth of non-OECD countries. In case of OECD countries, the results were inconclusive.
Better financial intermediaries and strong financial conditions probably offset the decline in growth rate by inflation in the countries where inflation was not high as in South Asia. Levine and Renelt (1992), using a wide range of macroeconomic, trade, political and institutional variables, also reached a similar conclusion using cross-country regression. Barro (1995) also supported the conclusion regarding non-OECD countries but his investigation regarding central bank independence and prior colonial rule as the instrument for inflation failed to capture the gravity of inflation. Cardoso (1992) investigated the inflation-poverty nexus of some selected countries of Latin America during 1970-1990 and found that the inflation tax reduced 0.3 percent of income, reduced real wage and increased poverty during 19771989. This study examined the hyperinflation that afflicted Latin America in the period of 1970-1990 where inequality was considerably higher.

Macroeconomic stability is deemed important for higher growth performance. Controlling budget deficit and high rate of inflation preceded the economic growth of Chile and Mexico. The fast growing East Asian countries also maintained low singledigit inflation for several decades. Romer and Romer (1998) revealed low inflation and macroeconomic stability associated with higher income of the poor in many developing countries. Fischer (1993) investigated various macroeconomic factors for growth and found insignificant negative association between inflation and growth but significant positive association between inflation and factor productivity and negative association between inflation and capital accumulation.

Perception of inflation is always negative as poor people consider price hike as robbing of their money and a decline in real income. In a survey-based study Schiller (1996) revealed 


\section{Articles}

that $77 \%$ of the respondents reported inflation makes them poorer. Moreover, $75 \%$ in the USA, $72 \%$ in Germany and $54 \%$ in Brazil wanted to see inflation at $2 \%$ in the situation of $9 \%$ unemployment rate. Respondents were more averse to inflation. In similar front, Easterly and Fischer (2001) used Probit model and found that as the standard of living decreases, the likelihood of mentioning inflation as the top concern increases. The poor are 14\% more likely to mention inflation as the top concern in both developed and developing countries.

Ivanic and Martin (2008) examined the food price inflation and poverty in the case of Pakistan during the second half of 2000s and found that the poverty gap widened by $1.6 \%$. But, Walsh and Jiangyan (2012) exposed the non-food inflation associated with rising income inequality in China and India in both urban and rural areas. But food price inflation tended to reduce poverty as the majority of the poor were farmers.

\subsection{Inflation, Growth and Income Distribution}

Since the seminal work of Simon Kuznet in 1950s, many economists have regarded inequality as an unavoidable precondition of growth. Inequality is necessary for the accumulation of wealth in the hands of a few for the subsequent investment and income generation for all. Trickle down effects of economic activities permit inequality because it allows the rich to secure a greater return on their asset, accumulation of wealth and subsequent expenditure that, to a large extent, goes to the low-income people. But Person and Tabellini (1990), and Alesina and Rodrick (1991) and Clarke (1993) all conclude that greater inequality slows down the growth prospect. Datt and Ravallion (1991) also examined these factors in the case of Brazil and India as representative of Asian and Latin American developing economies and found that the two variables had an uneven effect
Inflation, Growth, and Distribution Nexus in Post-

Transition and Emerging Economies of South Asia

on poverty reduction. Ravallion (2001) did not find any co-linearity between the level of per capita household income and the change in inequality. With the given inequality, in India, the rich get richer with their income growing four times faster than that of the poor. In Brazil, the growth of income of the rich is nineteen times faster than the poor in the given level of inequality. He plotted proportional change in poverty rate to the growth in average income and found that $1 \%$ increase in the average income reduces poverty at USD1/day by $2.5 \%$. Furthermore, countries with higher initial inequality tend to grow at lower rates, if the initial average income, openness to trade and rate of inflation are controlled. Inequality slows the growth rate in the economy through imperfect capital market, political and socioeconomic stability and reduces the saving rate according to Barro (2000). Kraay (2006) considers property rights another important parameter to have pro-poor growth in different instances of macroeconomic shocks.

During the 1990s there was an intense debate over poverty reducing effect of growth and globalization. It was argued against that the beneficial effects of growth on the poor are offset by sharp increase of inequality. On this issue, one of the most important papers was written by Dollar and Kraay (2002). They defined the lowest quintile of the income group as the poor and examined the relation between growth of the poor 's average income and the overall income growth covering both developed and developing countries for a period of forty years. The research showed that the income of the poorest one fifth has risen or fallen at the same rate as that of the national average. Protection of property rights, macroeconomic stability and openness of trade could enhance the income of the poor as well as others in the economy; no trickle-down effect was apparent to benefit the poor. 


\section{Articles}

Another approach of growth and income distribution is the investigation of reverse causal relation against the Kuznet's inverted ' $U$ ' hypothesis and trickle-down effect of wealth accumulation by the rich. Barro (2000) investigated inequality, growth and investment in a panel of countries and found insignificant association between them. Inequality slows down the growth prospect in poor countries but accelerates growth in richer countries. The results also show that with higher inequality, growth falls when per capita GDP is below US 2000 and rises when it is above USD 2000 (1985 USD).

\section{Methods}

\subsection{The Objectives, Hypotheses and Data}

This paper aims to investigate the impact of inflation on poverty and income distribution with reference to the economies of South Asia.

Countries with more equality are found growing faster than the less equal countries. East Asia is shown as an example. East Asian countries grew rapidly and high-inequality Latin American and African countries grew very slowly. South Asia with relatively low inequality in distribution of income is not growing sustainably compared to the East Asian countries. What might be the causes?

This paper has a series of hypotheses. Growth is reducing inequality and poverty gap. Rising inflation might have induced inequality and abated the speed of poverty reduction. Furthermore, inflation, both the food and nonfood types, affects negatively the growth and income distribution of the lowest quintile population and increases the income share of the highest quintile, the rich. This is how inflation widens inequality.

This study has used World Development Indicators data, as well as IMF's International Financial Statistics. Furthermore, based on availability of consistent macroeconomic data, this study has selected five major economies of South Asia: India, Pakistan, Bangladesh, Sri Lanka, and Nepal and has formed a panel of 28 years. Given the gap of required data from the common external source, the study has bridged this gap from national statistics available from the respective government sources. Although data are from multiple sources, they are consistent to each other.

\subsection{Empirical Model}

To answer the question as to why the countries of South Asia are lagging behind in growth and poverty reduction and whether inflation has anything to do with that, this paper uses the model developed by Barro (1995) and Sala-I-Martin (1997). Moreover, inflation as an explanatory variable has been more specifically used in terms of food and consumers price index inflation. The study has examined inflation's impact on three major indices of poverty: head count ratio, poverty gap and the overall inequality in the economy.

\section{Model: Poverty regression}

$Y_{i t}=\beta_{0}+\beta_{1 i} \pi_{i t}+\beta_{m i} X_{i t}+\beta_{i} D_{i}+\varepsilon_{i t}$

Where,

Dependent Variables $Y$ is

i) Head count poverty ratio

ii) Gini coefficient

iii) Income share of different quintiles, and iv) Poverty gap index.

Variable of interest is $\pi$ : the rate of inflation (Inflaindex), lagged Inflationindex, and food inflation.

$X$ is the set of control variables: GDP growth rate, population growth rate, saving, consumption expenditure, level of investment, debt servicing, trade openness, are all the variables included in the growth regression. Many of these variables are also used by Barro (1995) and Sala-I-Martin (1997) in their 


\section{Articles}

models. The levels of poverty and inequality have strong colinearity with these variables. However, we have added level of investment and trade openness as well because these two variables are apparently improving in South Asia over the years and they are considered to have influence on poverty and inequality. To put it in other words, there are two conditions under which the benefit from the trade reaches this group; first whether investment is labour intensive and trade openness penetrates the global markets; second the poor are working in the tradable sector so that the gain from international trade also reaches this group.

Country dummy included in the model are Dl for India, D2 for Nepal, D3 for Pakistan and $D 4$ for Sri Lanka.

$\beta$ refers to the coefficients of the variables in regressions, $i$ - to the number of variables
Inflation, Growth, and Distribution Nexus in Post-

Transition and Emerging Economies of South Asia

in each block of variables, and $t-$ to the time subscript.

\section{Findings}

This study has used the panel of 28 years of data for the five major economies of South Asia. Table 1 presents a summary statistics of the variables used in the model: GDP growth rate, population growth rate, trade openness, rate of inflation, and the rate of food price inflation. In a similar fashion, the study also uses consumption expenditure, investment expenditure, debt servicing, and gross domestic saving as a percentage of GDP. The table reveals that South Asian countries have grown four to six percent per year over the last three decades. Furthermore, the population growth rate remained less than two percent per year except in Pakistan where the growth rate is more than 2.5 percent per year (Table 1).

Table 1. Summary Statistics of the Variables Used (1986 - 2018) ${ }^{1}$

\begin{tabular}{|c|c|c|c|c|c|}
\hline \multirow{2}{*}{ Variables } & \multicolumn{5}{|l|}{ Countries } \\
\hline & Bangladesh & India & Nepal & Pakistan & Sri Lanka \\
\hline GDP growth rate & $\begin{array}{l}5.31 \\
(1.30)\end{array}$ & $\begin{array}{l}6.30 \\
(1.94)\end{array}$ & $\begin{array}{l}4.52 \\
(1.83)\end{array}$ & $\begin{array}{l}4.47 \\
(1.83)\end{array}$ & $\begin{array}{l}4.95 \\
(4.95)\end{array}$ \\
\hline Population growth rate & \begin{tabular}{|l|}
1.74 \\
$(0.55)$
\end{tabular} & \begin{tabular}{|l|}
1.65 \\
$(0.37)$
\end{tabular} & \begin{tabular}{|l|}
1.55 \\
$(0.89)$
\end{tabular} & \begin{tabular}{|l|}
2.53 \\
$(0.37)$
\end{tabular} & $\begin{array}{l}0.89 \\
(0.30)\end{array}$ \\
\hline Trade openness ${ }^{2}$ & $\begin{array}{l}31.16 \\
(9.70)\end{array}$ & \begin{tabular}{|l}
32.52 \\
$(14.30)$
\end{tabular} & $\begin{array}{l}46.80 \\
(8.44)\end{array}$ & $\begin{array}{l}33.26 \\
(3.53)\end{array}$ & $\begin{array}{l}66.41 \\
(12.57)\end{array}$ \\
\hline Rate of inflation ${ }^{3}$ & $\begin{array}{l}4.56 \\
(4.34)\end{array}$ & \begin{tabular}{|l|}
4.89 \\
$(2.28)$
\end{tabular} & $\begin{array}{l}4.89 \\
(2.36)\end{array}$ & $\begin{array}{l}5.45 \\
(2.32)\end{array}$ & $\begin{array}{l}5.30 \\
(2.82)\end{array}$ \\
\hline Rate of food price inflation ${ }^{4}$ & \begin{tabular}{|l}
6.16 \\
$(1.71)$
\end{tabular} & $\begin{array}{l}3.93 \\
(2.51)\end{array}$ & $\begin{array}{l}2.02 \\
(1.01)\end{array}$ & $\begin{array}{l}2.85 \\
(1.92)\end{array}$ & $\begin{array}{l}4.85 \\
(4.87)\end{array}$ \\
\hline Rate of domestic saving ${ }^{5}$ & $\begin{array}{l}18.78 \\
(3.60)\end{array}$ & $\begin{array}{l}27.05 \\
(5.34)\end{array}$ & $\begin{array}{l}11.37 \\
(2.67)\end{array}$ & $\begin{array}{l}12.30 \\
(3.71)\end{array}$ & $\begin{array}{l}18.90 \\
(2.91)\end{array}$ \\
\hline
\end{tabular}

${ }^{1}$ Data source: World Development Indicators, World Bank

${ }^{2}$ Trade openness is (import+export)/GDP

${ }^{3}$ Based on Consumer's price index $(2010=100)$, IFS data, IMF

${ }^{4}$ Food and non-alcoholic beverages, expressed as the percentage change from previous period

${ }^{5}$ Gross domestic savings (\% of GDP) 
Articles

\begin{tabular}{|l|l|l|l|l|l|}
\hline \multirow{2}{*}{ Variables } & \multicolumn{4}{l}{ Countries } & \multicolumn{4}{l|}{} \\
\cline { 2 - 6 } & Bangladesh & India & Nepal & Pakistan & Sri Lanka \\
\hline Consumption expenditure $^{6}$ & 81.22 & 72.96 & 88.63 & 87.70 & 81.09 \\
& $(3.61)$ & $(5.34)$ & $(2.67)$ & $(3.71)$ & $(2.91)$ \\
\hline Investment expenditure $^{7}$ & 7.98 & 8.63 & 15.80 & 6.10 & 8.49 \\
& $(2.46)$ & $(9.00)$ & $(12.20)$ & $(3.45)$ & $(6.04)$ \\
\hline Debt service $^{8}$ & 12.69 & 14.67 & 9.07 & 19.72 & 13.29 \\
& $(10.33)$ & $(10.92)$ & $(1,94)$ & $(7.61)$ & $(5.67)$ \\
\hline Number of observation & 28 & 28 & 28 & 28 & 28 \\
\hline
\end{tabular}

Note: Figures in the parentheses refer the standard deviation of the corresponding series.

Trade openness is about one-third of the GDP in many South Asian countries except that of Sri Lanka (66\%) and Nepal (47\%). However, the rate of domestic saving is fairly high in India, which is the fastest growing economy in the region (27\%), followed by Bangladesh and Sri Lanka (18\%). The lowest saving ratio in Nepal (11\% of GDP) and that of Pakistan $(12 \%)$ is consistent with the slowest economic growth in these two economies. Conversely, the consumption ratio is highest in Nepal and Pakistan compared to other countries of the region. Table 1 shows that debt servicing is quite high in Pakistan (20\% of GDP) and the lowest in Nepal. The rate of inflation remained between four to six percent whereas the food price inflation remained between two to six percent during 1986-2014.

In the following section, we present and analyze the impact of inflation on the poverty and inequality along with many control variables used in the model.

\subsection{Growth and Poverty}

South Asian countries have shown quite similar pattern of poverty and income distribution. The head count poverty ratio is taken at USD1.25/day, given that the income per capita, food habit, dependence on agriculture, widespread rural poverty but increasing urban poverty trends are common in all countries.

Poverty measurements are mainly from two approaches: the welfare approach and the monetary approach measured by consumption expenditure. In the welfare approach, economists assume rational choices of the consumers regarding income, consumption and human capabilities. In the monetary approach, expenditure acts as an indicator for the wellbeing. As expenditure data is less available than income data, the latter is taken as the proxy of expenditure. This makes a minimum level of income as poverty line and the people below that income level are considered as poor. Another approach of measuring poverty is by taking minimum nutritional standard or basic human necessities and income required to meet that demand is set as the poverty line. Hence people who fail to have that income are defined as the poor.

In this study we follow the minimum income required to meet the basic requirements as the definition of poverty line. This has been set as USD 1.25/day. On this basis, poverty is investigated for the following three indices:

- The Head Count Index measuring prevalence of poverty

\footnotetext{
${ }^{6}$ Final consumption expenditure ( $\%$ of GDP)

${ }^{7}$ Gross domestic capital formation (annual \% growth)

${ }^{8}$ Debt service: (The World Bank and IMF only, expressed as a \% of exports of goods, services and primary income)
} 


\section{Articles}

- The Poverty Gap Index measuring the depth of poverty

- Income Inequality.

The head count index is measured as the proportion of population that lives below the poverty line. With this we can estimate the number of people living below the poverty line whereas the poverty gap estimates the income necessary to bring the poor above the poverty line. The gap, therefore, is the average income required to the poor in order to bring them out of the poverty line.

Some prefer to use the share in the national income of the poorest quintile of the entire population as one proxy to measure poverty. Likewise, income inequality represented by the Gini index suggests how the national income is distributed among the entire population. Although GINI Index is the measure for inequality, it is often included in the group of poverty indicators.

In this section poverty indicators mentioned above are examined along with some fiscal and monetary variables.
Inflation, Growth, and Distribution Nexus in Post-

Transition and Emerging Economies of South Asia

\subsubsection{Growth and Poverty Rate}

Here the proposed model is examined using both fixed and random effect methods. In the fixed effect model, country dummy variable is included to investigate the country specific effect. In this model, the estimated result shows that the growth is positively correlated with head count poverty index. In other words, GDP growth rate in South Asia is not trickled down to benefit the poor -instead it is concentrated in the higher income group. However, this result is not statistically significant (Table 2).

Controlling population growth rate remained a challenge for South Asia for a long period. It is only in the current decade (after 2010), most of the countries have brought down the population growth rate to about $1.5 \%$. It is causing poverty in South Asia as shown by the first four models in Table 2 but this relation is not statistically significant. However, population growth is increasing the poverty level in association with the food price inflation as revealed by model 4 in this table.

Table 2. Growth, Inflation and Poverty Rate (Dependent Variable: Head Count Poverty Rate)

\begin{tabular}{|c|c|c|c|c|}
\hline Variable & EQ1(FE) & EQ2(RE) & EQ3(RE) & EQ4(FE) \\
\hline Intercept & $36.4059 * * *(0.000)$ & $61.8212^{\star * *}(0.000)$ & $62.00466^{\star * *}(0.000)$ & $25.8237 * * \star(0.000)$ \\
\hline Inflaindx & $-.284467^{\star * \star}(0.000)$ & $-.28855^{\star \star \star}(0.000)$ & & \\
\hline Inflaindx1 & & & $-.306393^{* * *}(0.000)$ & $-.34546 * * *(0.000)$ \\
\hline GDP & $.15469(0.483)$ & $.042569(0.851)$ & $-.0269744(0.901)$ & $.350566(0.165)$ \\
\hline PGro & $.834846(0.515)$ & $.813775(0.536)$ & $1.5818(0.206)$ & $-.5665053(0.635)$ \\
\hline Foodprice & & & & $.050139 * * *(0.000)$ \\
\hline Tradeopenness & -.0006985 (0.954) & $-.00054(0.965)$ & $.0003105(0.979)$ & $.006143(0.511)$ \\
\hline Saving & $1.08184^{* * *}(0.000)$ & $.78612^{\star * *}(0.000)$ & $.84028 * * *(0.000)$ & 1.44446 *** $(0.000)$ \\
\hline Consumptionexp. & $2.60134^{\star * \star}(0.000)$ & $2.34598 * * *(0.000)$ & $2.219 * \star *(0.000)$ & $2.968811^{* * *}(0.000)$ \\
\hline Investment & $-.6205319 * * *(0.001)$ & $-.20331(0.211)$ & $-.25740 *(0.092)$ & $-1.02590 * * *(0.000)$ \\
\hline Debtservice & $-.9328393^{\star}(0.066)$ & $-1.50367^{* * *}(0.002)$ & $-1.447618^{* * *}(0.002)$ & $1.18553^{\star}(0.081)$ \\
\hline D1 & & $-33.5662^{\star \star *}(0.000)$ & $-33.4946^{\star * \star}(0.004)$ & \\
\hline $\mathrm{D} 2$ & & $-5.3953^{* * *}(0.007)$ & $-5.5953^{* * *}(0.000)$ & \\
\hline D3 & & $-25.811(0.000)$ & $-26.3783(0.000)$ & \\
\hline D4 & & $-58.2600 * \star *(0.000)$ & $-57.9056^{\star * *}(0.000)$ & \\
\hline
\end{tabular}




\section{Articles}

\begin{tabular}{|l|l|l|l|l|}
\hline Variable & EQ1(FE) & EQ2(RE) & EQ3(RE) & EQ4(FE) \\
\hline R2 & Wthn. 0.842 & Wthn.0.833 & Wthn.0.849 & Wthn. 0.862 \\
& Btwn.0.068 & Btwn.0.999 & Btwn.0.999 & Btwn.0.264 \\
& Ovll. 0.021 & Ovll. 0.955 & Ovll. 0.959 & Ovll. 0.065 \\
\hline
\end{tabular}

Note: Figures in the parentheses are P-value

$\left({ }^{*},{ }^{* *}\right.$, and ${ }^{* * *}$ indicate significance level at $10 \%, 5 \%$ and $1 \%$, respectively.)

Trade liberalization in South Asia started in the 1990s and consequently economic activities in most of the countries were affected with a likely impact on distribution as well. Similar to the experience of many African economies, trade openness has marginalized the poor in South Asia (Table 2). The level of domestic saving and consumption expenditure also do not tend to reduce poverty and the results are statistically significant at $1 \%$ level of significance. The saving data refers to the overall domestic saving. People below the poverty line are unable to save; therefore, higher growth of income and savings are concentrated among the richer section of society. Furthermore, inflation reduces the savings and increases the consumption expenditure which in turn aggravates the poverty situation.
The level of investment and debt service significantly reduce poverty but with the inclusion of country dummy variable the investment coefficient becomes insignificant.

\subsubsection{Growth and Poverty Gap Index}

The inflation during the current and the preceding year contributes to reducing the poverty gap (Table 3 ). However, the small landholders and landless population poorest of the poor - face the loss of income if the inflation originates from the food prices. In this situation, the poverty gap widens. High population growth and consumption expenditure definitely raise the poverty gap. Similar to the impact on poverty, trade openness does not contribute to the reduction of poverty gap implying that poor are less integrated to the global market and are unable to reap the benefit of rising prices.

Table 3. Growth, Inflation and Poverty Gap (Dependent Variable: Poverty Gap)

\begin{tabular}{|c|c|c|c|c|}
\hline Variable & EQ1(FE) & EQ2(RE) & EQ3(RE) & EQ4(FE) \\
\hline Intercept & $7.59623^{\star \star *}(0.002)$ & $17.20211^{* * *}(0.000)$ & $17.1585^{\star \star *}(0.000)$ & $6.35322^{* * *}(0.006)$ \\
\hline Inflaindx & $-.1336733^{* * *}(0.000)$ & $-.132829 * * *(0.000)$ & & \\
\hline Inflaindx1 & & & $-138813^{* * *}(0.000)$ & $-.150924 * * *(0.000)$ \\
\hline GDP & $.0708844(0.520)$ & $-.032175(0.789)$ & $-.0541476(0.644)$ & $.1582346(0.190)$ \\
\hline PGro & $.518693(0.435)$ & $.7695486(0.290)$ & $1.258474^{*}(0.073)$ & $-.346352(0.568)$ \\
\hline Foodprice & & & & $.0248496^{* * *}(0.000)$ \\
\hline Tradeopenness & $-.001299(0.838)$ & $-.0020446(0.769)$ & $-.002118(0.755)$ & $.001062(0.831)$ \\
\hline Saving & $.506294^{* \star \star}(0.000)$ & $.2522586^{* * *}(0.002)$ & $.2759165^{\star \star \star}(0.001)$ & $.5748979 * * *(0.000)$ \\
\hline Consumptionexp. & $1.46109^{* * *}(0.000)$ & $1.25099^{* * *}(0.000)$ & $1.166149^{* * *}(0.000)$ & $1.43449 * * \star(0.000)$ \\
\hline Investment & $-.264879 * * *(0.003)$ & $.069273(0.400)$ & $.0361468(0.646)$ & $-.430937^{* \star *}(0.000)$ \\
\hline Debtservice & $-.8290026^{* \star *}(0.001)$ & $-1.10757^{* * *}(0.000)$ & $-1.04798^{* * *}(0.000)$ & $-.2529896(0.385)$ \\
\hline DI & & $-15.7586^{* * *}(0.000)$ & $-15.5746^{* * *}(0.000)$ & \\
\hline D2 & & $-.006335(0.995)$ & $-.0737987(0.942)$ & \\
\hline
\end{tabular}




\begin{tabular}{|c|c|c|c|c|}
\hline Variable & EQ1(FE) & EQ2(RE) & EQ3(RE) & EQ4(FE) \\
\hline D3 & & $-11.7919 * * *(0.000)$ & $-12.1146 * * *(0.000)$ & \\
\hline D4 & & $-22.0079 * * *(0.000)$ & $-21.6523^{* * *}(0.000)$ & \\
\hline $\mathrm{R} 2$ & $\begin{array}{l}\text { Wthn.0.830 } \\
\text { Btwn.0.200 } \\
\text { Ovll. } 0.023\end{array}$ & $\begin{array}{l}\text { Wthn.0.799 } \\
\text { Btwn.0.998 } \\
\text { Ovll. } \quad 0.918\end{array}$ & $\begin{array}{l}\text { Wthn.0.811 } \\
\text { Btwn.0.998 } \\
\text { Ovll. } \quad 0.923\end{array}$ & $\begin{array}{l}\text { Wthn.0.826 } \\
\text { Btwn. } 0.517 \\
\text { Ovll. } 0.082\end{array}$ \\
\hline
\end{tabular}

Note: Figures in the parentheses are $\mathrm{P}$-value

$\left({ }^{*},{ }^{* *}\right.$, and ${ }^{* * *}$ indicate significance level at $10 \%, 5 \%$ and $1 \%$, respectively.)

Investment and debt service reduce the poverty gap. Among these control variables, only the coefficient of debt service is statistically significant. Investment is negative in the fixed effect model but in the random effect model with the inclusion of country dummy, it becomes positive but insignificant. Except for Nepal, all four countries determine this relation. Therefore, the mode of total investment in Bangladesh, India, Pakistan and Sri Lanka has not been established as pro-poor so far. Furthermore, as the income growth is more concentrated among the high income group, the saving is also pro-rich and not supportive to reduce the poverty gap (Table 3).

\subsubsection{Growth and Income Inequality}

In his groundbreaking paper Simon Kuznet (1955) disclosed that with the higher economic growth, inequality increases then again it declines. Todaro and Smith (2012) point "There are now enough case studies and specific examples of countries such as Taiwan, South Korea, Costa Rica, and Sri Lanka to demonstrate that higher income levels can be accompanied by falling and not rising inequality." Similar is the case in South Asia.

Table 4. Growth, Inflation and Income Inequality (Dependent Variable: GINI Index)

\begin{tabular}{|c|c|c|c|c|}
\hline Variable & EQ1(FE) & EQ2(RE) & EQ3(RE) & EQ4(FE) \\
\hline Intercept & 50.86823 *** $(0.000)$ & $33.26935^{\star \star \star}(0.000)$ & $32.41214^{* * *}(0.000)$ & $35.84167^{\star * *}(0.000)$ \\
\hline Inflaindx & $.1406132^{* *}(0.040)$ & $.0405445^{\star \star \star}(0.000)$ & & \\
\hline Inflaindx1 & & & $.061087^{\star * *}(0.000)$ & $.0846096^{* * *}(0.000)$ \\
\hline GDP & $-.0213485(0.930)$ & $-.0906986(0.404)$ & $-.1006148(0.336)$ & $-.0059528(0.965)$ \\
\hline PGro & $-.9652595(0.143)$ & $-.9450943(0.148)$ & $-.481385(0.449)$ & $-.8516732(0.219)$ \\
\hline Foodprice & & & & $-.0269335^{\star * *}(0.000)$ \\
\hline Tradeopenness & $.0130349^{* *}(0.043)$ & $.0126421^{* *}(0.046)$ & $.009968(0.105)$ & $.0094553^{*}(0.098)$ \\
\hline Saving & $.3307554^{* \star *}(0.000)$ & $.326928^{* * *}(0.000)$ & $.299330 * * *(0.000)$ & $.3348123^{* * *}(0.006)$ \\
\hline Consumption exp. & $-.1620831(0.226)$ & $-.1569177(0.232)$ & $-.183507(0.145)$ & $-.2940464^{* *}(0.052)$ \\
\hline Investment & $-.3263921^{* \star *}(0.000)$ & $-.3203293^{* * *}(0.000)$ & $-.343366^{* * *}(0.000)$ & $-.1751537(0.121)$ \\
\hline Debtservice & $-.3734586(0.120)$ & $-.3420627(0.139)$ & $-.2671322(0.226)$ & $.3087823(0.346)$ \\
\hline DI & & $1.81190(0.145)$ & $2.43295^{\star \star}(0.044)$ & \\
\hline $\mathrm{D} 2$ & & $8.231409 * * \star(0.000)$ & $8.247489 * * *(0.000)$ & \\
\hline D3 & & $6.8024^{* * *}(0.000)$ & $6.63099 * * *(0.000)$ & \\
\hline D4 & & $8.05219 * * *(0.000)$ & $8.85630 * \star *(0.000)$ & \\
\hline
\end{tabular}




\begin{tabular}{|l|l|l|l|l|}
\hline Variable & EQ1(FE) & EQ2(RE) & EQ3(RE) & EQ4(FE) \\
\hline \multirow{2}{*}{ R2 } & Wthn. 0.357 & Wthn. 0.492 & Wthn. 0.475 & Wthn. 0.429 \\
& Btwn.0.207 & Btwn.0.998 & Btwn.0.999 & Btwn.0.179 \\
& Ovll. 0.056 & Ovll. 0.674 & Ovll. 0.656 & Ovll. 0.049 \\
\hline
\end{tabular}

Note: Figures in the parentheses are $P$-value

$\left({ }^{*},{ }^{* *}\right.$, and ${ }^{* * *}$ indicate significance level at10\%, 5\% and1\%, respectively.)

Closer scrutiny of Table 2, 3, and 4 reveals that in South Asia inflation reduces poverty but deepens inequality. However, the impact of food price inflation is slightly different. It raises poverty and the poverty gap (Table 2 and 3 ) but reduces inequality (Table 4). Both of these effects of food price inflation are statistically significant even at one percent level. On the other hand, GDP growth has neither significant impact on poverty nor inequality. Furthermore, trade openness is still unable to bring pro-poor growth effect in South Asian countries. Likewise, the higher the savings are, the higher the income inequality, given that savings are more concentrated among the rich.

Population growth rate, consumption expenditure, debt service and investment all reduce income inequality; however, the result is significant only in the case of investment expenditure. The only plausible explanation behind this is that poor get access to employment and benefit from increasing investment also supported by public sector borrowing. There might be crowding-in effect in this connection. Population growth and consumption expenditure definitely raises the demand for food prices which in turn benefits farmers. Therefore, when there is food price inflation coupled with increasing consumption expenditure, both factors have a significant effect on reducing inequality. This is very important and interesting conclusion drawn from the fourth model (last column) presented in Table 4.

\section{Conclusion}

This study has attempted to examine inflation, growth and distribution nexus in South Asia. Using the time series data during 28 years (1986-2014) in five major South Asian countries - India, Pakistan, Sri Lanka, Bangladesh, and Nepal -a panel data of major macroeconomic indicators were formed. This has made it possible to diagnose the impact of inflation on growth and distribution in these emerging economies. In addition to the fixed effect model, the study has created countryspecific dummies and used the random effect model as well.

Trade openness has marginalized the poor in South Asia. The levels of domestic savings and consumption expenditure have not been found to reduce poverty. People below the poverty line are unable to save; therefore, higher growth of income and savings are concentrated among the richer section of society. Even among the poor, inflation reduces the savings and increases the consumption expenditure which in turn aggravates the poverty situation.

The inflation of the current and the preceding year contributes to reducing the poverty gap. However, the small landholders and landless population - poorest of the poor face the decline of their income if the inflation originates from food prices. In this situation, the poverty gap widens. High population growth and consumption expenditure definitely raise the poverty gap. Similar to the impact on poverty, trade openness does not contribute to the reduction of poverty gap implying that poor are less integrated to the global market 


\section{Articles}

and are unable to reap the benefit of rising prices in the global market. Investment and debt service, for their part, reduce the poverty gap. So far, the mode of investment does not prove itself as pro-poor in South Asia. As the income growth is more concentrated among the high income group, the saving is also prorich and not supportive to the reduction of the poverty gap.

In South Asia, inflation increases inequality as has become evident from the two models used in this study. Yet food price inflation reduces inequality. The result is also consistent with respect to the income share of the poorest quintile of the population. On the other hand, GDP growth definitely reduces inequality but the growth performance of South Asian economies being pro-rich, reduction in inequality is not significant. Likewise, trade openness is not yet pro-poor. As savings are more concentrated among the rich; the higher the savings are, the higher the income inequality.

Population growth rate, consumption expenditure, debt service and investment all reduce income inequality; however, the result is significant only in case of investment expenditure. The only plausible explanation behind this is that poor get employment and get the benefits from increasing investment which is also supported by public sector borrowing. There might be crowding-in effect in this connection. Population growth and consumption expenditure definitely raise the demand for food prices from which farmers benefit. Therefore, when there is food price inflation coupled with increasing consumption expenditure, these two factors have a significant effect on reducing inequality. This is a very important and interesting conclusion drawn from this study.
Inflation, Growth, and Distribution Nexus in Post-

Transition and Emerging Economies of South Asia

\section{REFERENCES:}

Acharya, S., and Cohen, S., 2008. Trade liberalization and household welfare in Nepal. Journal of Policy Modelling, 30(2008), 10571060.

Acharya, S., Holscher, J., and Perugini, C., 2012. Trade liberalization and inequalities in Nepal. Journal of Economic Modelling, 29(2012), 2543-2557.

Atkinson, A. B. 1991. Comparing Poverty Rates Internationally: Lessons from Recent Studies in Developed Countries. World Bank Economic Review, 5-I: 3-21.

Atkinson, A. B. 1987. On the Measurement of Poverty. Econometrica, 55(4): 749-764.

Anand, S., and Harris, C. 1992. Issues in the Measurement of Under-nutrition, inNutrition and Poverty. Oxford: Oxford University Press.

Barro R.J. 1995. Inflation and Economic Growth. NBER Working paper no. 5326, October, 1995.

Barro, R. J., 2000. Inequality and Growth in a Panel of Countries. Journal of Economic Growth, 5:5-32.

Blank, R.B., and Blinder, A.S., 1985. Macroeconomics, Income Distribution and Poverty. NBER Working Paper No. 1567.

Blinder, A. S., and Esaki H.Y., 1978. Macro Economic Activity and Income Distribution $\mathrm{m}$ the Postwar United States. Review of Economic and Statistics, p.604-609.

Cardosa, E., 1992. Inflation and Poverty. National Bureau of Economic Research.

Clarke, G.R.G. 1995. More Evidence on Income Distribution and Growth. Journal of Development Economics, Vol.47: 403-427.

Datt, G., and Ravallion, M., 1991. Growth and redistribution components of changes in poverty measures: A decomposition with applications to India in the 1980. Living Standards Measurement Study Working paper, World Bank, no.83 


\section{Articles}

Dollar, D., and Kraay, A. 2002. Growth is Good for the Poor. Journal of Economic Growth, 7: 195-225.

Driffill, J., Mizon, L., and Ulph, A., 1990. Costs of inflation, In Handbook of Monetary Economics, vol. 2, B. Friedman and F. Hahn (ed.), North-Holland.

Easterly, W., and Fischer. S., 2001. Inflation and the Poor. Journal of Money, Credit and Banking, Vol.33, No. 2 Part 1, pp 160-178.

Fischer, S., 1993. The role of Macroeconomic Factors in Growth. Journal of Monetary Economics, 32(1993) 485-512.

Fischer, S., and Modigliani, F., 1978. Towards an Understanding of the Real Effects and Costs of inflation. Weltwirtschaftliches Archive 114: 810-833.

Grier, K. B., and Tullock, G., 1989.An Empirical Analysis of Gross National Economic Growth. Journal of Monetary Economics, 24: 259-276.

Ivanic, M., and Martin, W.,2008. Implications of Higher Global Food Prices forPoverty in Low-Income Countries. Agricultural Economics 39(3):405 - 416.

Kraay, A., 2006. When growth is pro-poor? Evidence from a Panel Countries. Journal of Development Economics 80: 198-227.

Kuznets, S., 1955. Economic Growth and Income Inequality. American Economic Review Volume XLV.

Kormendi, R., and Meguire, P., 1985. Macroeconomic Determinants of Growth, Journal of Monetary Economics, Vol. 16.

Laidler, D., and Parkin, M., 1975. Inflation: A survey. Economic Journal 85, 741-809.

Levine, R. and Renelt, D., 1992. A Sensitivity Analysis of Cross-Country Growth Regressions. American Economic Review, 82(4): 942-963.

Mankiw, N. G., 2000. Macroeconomics, 4th Ed., New York.

Motley, B., 1994. Growth and Inflation: A Cross-Country Study, Federal Reserve Bank of San Francisco, Working Paper 94-08.9408.

RBI (Reserve Bank of India), 2008. Macroeconomic and Monetary Developments in 2007-08, Department of Communication, RBI, Mumbai.

Roemer, M., and Gugerty, M. K., 1997. Does Economic Growth Reduce Poverty? Technicalpaper, Harvard Institute for International Development.

Ravallion, M. 1997. Can High Inequality Developing Countries Escape Absolute Poverty?Economic Letters, 56 (1997) 51-57.

Ravallion, M. 2001. Growth, Inequality and Poverty: Looking Beyond Averages. World Development, 29(11): 1803-1815.

SAARC (South Asian Association for Regional Co-operation), 2013. SAARC Regional Poverty Profile 2010-2012, SAARC Secretariat, Kathmandu, Nepal.

Sala-I-Martin, X. X., 1997. I Just Ran Two Million Regression. The American Economic Review, 87(2):178-183

Sarel, M., 1995. Nonlinear Effects of Inflation on Economic Growth, Working paper WP/95/56, IMF, Washington DC,International Monetary Fund, www.imf.org.

Schiller, R., 1996. Why Do People Dislike Inflation, NBER working paper No. 5539.

Todaro, M. P., and Smith, S. C., 2012. Economic Development, 11th Edition, Addison Wesley.

Walsh, J. P and Yu, J., 2012. Inflation and Income Inequality: Is Food Inflation Different? IMF working paper.

World Bank, 2018. Bangladesh: Reducing Poverty and Sharing Prosperity, The World Bank, Washington DC.

World Bank, 2002. Poverty in Pakistan: Vulnerabilities, Social gaps and rural dynamics, Poverty Assessment Report for South Asia Region, Poverty Reduction and Economic Management Unit, The World Bank. 